\section{Moisture Content of Extensive Green Roof Substrate and Growth Response of 15 Temperate Plant Species during Dry Down}

\author{
Jennifer M. Bousselot ${ }^{1,2}$, James E. Klett, and Ronda D. Koski \\ Colorado State University, Department of Horticulture and Landscape \\ Architecture, Campus Delivery 1173, Fort Collins, CO 80523
}

Additional index words. volumetric moisture content (VMC), Allium cernuum, Antennaria parvifolia, Artemisia frigida, Bouteloua gracilis, Buchloe dactyloides, Carex flacca, Delosperma cooperi, Delosperma nubigenum, Penstemon pinifolius, Sedum acre, Sedum album, Sedum lanceolatum, Sedum spurium 'John Creech', Sempervivum 'Royal Ruby', Thymus pseudolanuginosus

\begin{abstract}
Success of extensive green roof vegetation depends primarily on associated plant species' ability to survive the low moisture content of the substrate. As a result of the well-drained nature of the substrate, plants adaptable to dry, porous soils are primarily used in extensive green roof applications. Although Sedum species have dominated the plant palette for extensive green roofs, there is growing interest in expanding the plant list for extensive green roof systems. To effectively select suitable plants, species need to be evaluated in terms of their response to gradual and prolonged dry down of the substrate. A study to determine the relative rates of dry down for 15 species was conducted in greenhouse trials. During dry downs that extended over 5 months, the substrate of succulent and herbaceous species dried down at different rates. The change in moisture content of the substrate was not consistent among succulent and herbaceous plant species during the initial $18 \mathrm{~d}$ of dry down. Despite differences in rate of dry down, the succulent species, as a group, maintained viable foliage for over five times longer than the herbaceous species. The revival rates of the succulent species were nearly double those of the herbaceous species. Therefore, not only are succulent species more likely to survive during periods of drought, but these species are more likely to resume growth soon after water is again made available.
\end{abstract}

Green roofs provide many benefits to urban communities and can be used to help alleviate the negative effects of urbanization (Getter and Rowe, 2006; Oberndorfer et al., 2007). A healthy vegetation layer is essential for achieving these benefits. Therefore, knowledge about plant tolerance to severe moisture stress is essential, especially in a system such as an extensive green roof where moisture is typically a limiting factor for plant health. The substrate used for extensive green roofs is lightweight, well drained, and prone to extreme fluctuations in moisture content. As a result of the characteristics of the substrate, plant species used in extensive green roof systems, among other things, must be able to adapt to periods of low moisture availability in their root zones.

Received for publication 30 Sept. 2010. Accepted for publication 15 Dec. 2010.

Funding and support for this study was provided by the Environmental Protection Agency through a Cooperative Agreement (83350101-0); this article was not subject to the Agency review process. This paper is a portion of a $\mathrm{PhD}$ dissertation submitted by Jennifer M. Bousselot

${ }^{1}$ Current mailing address: Iowa State University, Department of Horticulture, 137 Horticulture Hall, Ames, IA 50011-1100.

${ }^{2}$ To whom reprint requests should be addressed; e-mailjmbouss@iastate.edu.
Succulents, especially species of Sedum, have been the most studied and used plants for green roofs (Berghage et al., 2007; Dunnett and Nolan, 2004; Durhman et a1., 2006, 2007; Emilsson, 2003; Kircher, 2004; Latocha and Batorska, 2007; Monterusso et al., 2005; Nagase and Thuring, 2006; Sendo et al., 2007; Snodgrass and Snodgrass, 2006; VanWoert et al., 2005). One of the main reasons Sedums seem ideally suited to green roof cultivation is the fact that many possess Crassulacean acid metabolism (CAM). During periods of soil moisture deficit, CAM plants keep their stomata closed during the day when transpiration rates are normally high and open them at night when transpiration rates are significantly lower. This is in contrast to $\mathrm{C} 3$ and $\mathrm{C} 4$ plants, which do not keep their stomata closed during the day and therefore have higher water use rates than CAM plants.

To avoid issues associated with Sedum monocultures, additional plant species will need to be incorporated into the extensive green roof plant palette. Sedum monocultures result in an unvarying, monotone effect (Dunnett and Nolan, 2004). Additionally, similar to row crop monocultures, these systems may have a higher probability of pest problems than a system that has diversity. Many examples can be found in agriculture that illustrate how plant species diversity affects pest populations, particularly how pest incidence increases in monocultures (Altieri and Letourneau, 1982). Therefore, it would be ideal to avoid potential future issues on extensive green roofs by diversifying plant selection.

Enhancing plant species biodiversity can make extensive green roofs attractive to regionally native arthropod and avian species (Wolf and Lundholm, 2008). Additionally, a diversified plant palette on an extensive green roof may be able to adapt to variable moisture conditions and maximize the evaporative cooling benefit, thus extending the benefits of extensive green roofs (Compton and Whitlow, 2006). Finally, green roofs can be used as an urban location to maintain plant biodiversity (Dunnett and Kingsbury, 2004).

Incorporating native plants into extensive green roof systems has been investigated by others; however, the research in this area suggests that very few plant species can match the growth and survival performance of the nonnative Sedum species (Dunnett and Nolan, 2004; Durhman et al., 2007; Kircher, 2004; Latocha and Batorska, 2007; Monterusso et al., 2005). This could be because the properties of the soils in which many native plants evolved are significantly different from those of the shallow well-drained, green roof substrate. Native plants should not be considered for use on green roofs based solely on the fact that they are adapted to local conditions (Dunnett, 2006).

Evaluating plants that are native to habitats characterized by growing conditions similar to shallow well-drained extensive green roofs may yield more favorable results. Plant communities that develop on shallow and well-drained soils, which mimic the conditions typical of an extensive green roof, may be sources of additional plant species suitable for extensive green roof culture. For example, plant species native to rocky and well-drained areas in Michigan have been incorporated into the plant palette for extensive green roofs in the Great Lakes region (Durhman et al., 2007). Semiarid areas in Colorado often possess shallow and welldrained soils and receive low annual precipitation often with extended periods of below-normal precipitation. Thus, plant species native to these areas may be well suited for use on extensive green roofs (Getter and Rowe, 2006) because they possess mechanisms that allow them to survive extending periods of suboptimal soil moisture conditions.

Regardless of plant species origin, the establishment, survival, and success of plants in an extensive green roof located in a semiarid region require irrigation (Bousselot, 2010). Predictions have been made that success of extensive green roofs in areas with infrequent precipitation events is improbable unless supplemental irrigation is provided (Miller, 2003).

Selection of plants for use on extensive green roofs should be based on the following criteria: tolerant of soil moisture deficit, lowgrowing growth habit (beneficial for extensive green roofs to obtain good coverage), evergreen foliage, and a long period of bloom. Plants with an erect growth habit can be used as accent plants (good for contrast with groundcovers in heights and bloom times). 
Plant species considered for use in extensive green roof systems need to be evaluated for their response to gradual and long-term drying of the substrate. Thus, relative rate of dry down for plant species considered for use in such systems is an important characteristic to assess. In semiarid regions, such knowledge will help to determine the need for irrigation and the frequency of irrigation events for these species. The goal of this study was to determine the impact of gradual drying of extensive green roof substrate on the growth of 15 plant species and to determine the relative water use for each of the 15 species.

\section{Materials and Methods}

Fifteen plant species were used in two dry down trials conducted in a greenhouse in northern Colorado. Environmental conditions for both of the greenhouse trials are summarized in Table 1. Experiments were performed 1 year apart in the Fall of 2008 and 2009.

For both trials, 24 propagules of each species were randomly selected from 128-cell plug trays of each respective species. The substrate was composed of five parts heat-expanded shale ( $50 \%$ by volume of 95 - to $63-\mathrm{mm}$ diameter particles, $30 \%$ by volume of 63 - to $20-\mathrm{mm}$ diameter particles and $20 \%$ by volume of greater than 20-mm diameter particles), two parts sphagnum peatmoss, two parts perlite, and one part vermiculite, by volume. The composition of the substrate was consistent across both trials (Table 2).

Individual propagules of each species (Table 3) were planted singly in containers and established for 10 weeks in a greenhouse. The containers used were circular green plastic $152 \mathrm{~mm}$ diameter by $108-\mathrm{mm}$ deep pots. Each container was filled with substrate to a depth of $100 \mathrm{~mm}$ to equal the depth of the substrate on a typical extensive green roof. Twenty-four replications per species were planted and laid out as a randomized complete block design. Pots were spaced equidistantly at $\approx 250$-mm centers on wire mesh greenhouse benches.

After planting in containers, plants were irrigated to saturation every $48 \mathrm{~h}$; this irrigation regimen was continued during the establishment period until $10 \mathrm{~d}$ before initiation of the dry down period. Then, irrigation was tapered to every $72 \mathrm{~h}$ between irrigation events for two irrigations and finally to $96 \mathrm{~h}$ before the final irrigation just before dry down initiation. At the final irrigation, all plants were irrigated with 450 $\mathrm{mL}$ and free drainage was allowed for at least $12 \mathrm{~h}$ before taking the first substrate moisture measurement. Fertilizer (Scotts Osmocote Pro 19-5-8; Scotts-Sierra Horticultural Products Co., Marysville, $\mathrm{OH}$ ) was applied at $5 \mathrm{~g}$ per propagule 4 weeks before dry down initiation. Pots containing substrate with no vegetation served as the non-vegetated controls and were used to evaluate evaporation.

Data collection and statistical analysis. For both trials, substrate volumetric moisture content (VMC) was recorded daily for each plant using a ThetaProbe ML2x (Delta-T Devices, Ltd., Cambridge, UK). The probe was inserted to $60-\mathrm{mm}$ depth in the substrate, at

Table 1. Environmental conditions daily means derived from measurements taken at 5-min intervals in the greenhouse trials (SES in parentheses).

\begin{tabular}{lccc}
\hline Trial & Temperature $^{\mathrm{z}}$ & Relative humidity $^{\mathrm{z}}$ & Solar radiation $^{y}$ \\
\hline Greenhouse $2008^{\mathrm{x}}$ & $21.85^{\circ} \mathrm{C}(0.05)$ & $57.73 \%(0.13)$ & $162.36 \mathrm{~W} \cdot \mathrm{m}^{-2}(1.87)$ \\
Minimum $/$ maximum & $9.21 / 35.08{ }^{\circ} \mathrm{C}$ & $25.08 / 84.63 \%$ & - \\
Greenhouse $2009^{\mathrm{w}}$ & $21.66^{\circ} \mathrm{C}(0.04)$ & $56.82 \%(0.16)$ & $163.13 \mathrm{~W} \cdot \mathrm{m}^{-2}(1.91)$ \\
Minimum $/$ maximum & $10.88 / 27.35^{\circ} \mathrm{C}$ & $22.84 / 90.10 \%$ & - \\
\hline
\end{tabular}

${ }^{2} \mathrm{HOBO} \otimes$ temperature and RH probe (U12 Onset Computer Corp., Bourne, MA).

${ }^{y}$ Precision pyranometer (SP-110; Apogee Instruments, Inc., Logan, UT).

${ }^{x}$ From 3 Sept. 2008 to 30 Sept. 2008.

${ }^{\mathrm{w}}$ From 3 Sept. 2009 to 30 Sept. 2009.

Table 2. Physical characteristics of the substrate used in both trials.

\begin{tabular}{llc}
\hline Substrate characteristic & \multicolumn{1}{c}{ Value } \\
\hline Bulk density & & $0.77 \mathrm{~g} \cdot \mathrm{cc}^{-1}$ \\
Particle density & & $2.20 \mathrm{~g} \cdot \mathrm{cc}^{-1}$ \\
Saturated hydraulic conductivity & & $0.0087 \mathrm{~cm} \cdot \mathrm{s}^{-1}$ \\
At maximum water capacity & Air content & $13.8 \%$ \\
& Water content & $51.1 \%$ \\
\hline
\end{tabular}

Table 3. Plant species evaluated in the study.

\begin{tabular}{|c|c|c|}
\hline Scientific name & Common name & Propagule source \\
\hline Allium cernuum Roth. & Nodding onion & Gulley Greenhouse, Fort Collins, $\mathrm{CO}$ \\
\hline Antennaria parvifolia Nutt. & Small-leaf pussytoes & Gulley Greenhouse, Fort Collins, CO \\
\hline Artemisia frigida Willd. & Fringed sage & Gulley Greenhouse, Fort Collins, CO \\
\hline $\begin{array}{l}\text { Bouteloua gracilis (Kunth) } \\
\text { Lag. ex Griffiths }\end{array}$ & Blue grama & Gulley Greenhouse, Fort Collins, CO \\
\hline Buchloe dactyloides (Nutt.) Engelm. & Buffalo grass & Gulley Greenhouse, Fort Collins, CO \\
\hline Carex flacca Schreb. & Sedge & Bluebird Nursery, Inc., Clarkson, NE \\
\hline Delosperma cooperi (Hook. f.) L. Bol. & Hardy ice plant & Gulley Greenhouse, Fort Collins, CO \\
\hline $\begin{array}{l}\text { Delosperma nubigenum (Schltr.) } \\
\text { L. Bol. }\end{array}$ & Yellow ice plant & Gulley Greenhouse, Fort Collins, CO \\
\hline Penstemon pinifolius Greene & Pineleaf penstemon & Gulley Greenhouse, Fort Collins, CO \\
\hline Sedum acre L. & Goldmoss stonecrop & Gulley Greenhouse, Fort Collins, CO \\
\hline Sedum album L. & White stonecrop & Bluebird Nursery, Inc., Clarkson, NE \\
\hline Sedum lanceolatum Torr. & Lanceleaf stonecrop & Gulley Greenhouse, Fort Collins, CO \\
\hline $\begin{array}{l}\text { Sedum spurium Marsch-Bieb. } \\
\text { 'John Creech' }\end{array}$ & Two-lined stonecrop & Gulley Greenhouse, Fort Collins, CO \\
\hline Sempervivum 'Royal Ruby' & Hens & Gulley Greenhouse, Fort Collins, CO \\
\hline Thymus pseudolanuginosus Ronn. & Woolly thyme & Gulley Greenhouse, Fort Collins, CO \\
\hline
\end{tabular}

least $10 \mathrm{~mm}$ from the edge of the container. Values were collected daily until VMC remained constant, which occurred $\approx 18 \mathrm{~d}$ after initiation of the dry down period. Relative water use for each species was estimated from substrate VMC data by subtracting the VMC of the non-vegetated control from the container VMC for each day.

The number of days to top growth dieback for each plant was also determined. The date when no viable green tissue, including both foliage and stems, remained above the substrate surface was recorded and used to determine the number of days to top growth dieback. On the day when no viable green tissue remained above the substrate surface, all plants were rewatered with $450 \mathrm{~mL}$ every $48 \mathrm{~h}$. This day was also the starting point to determine their revival ability.

Relative water use and days to top growth dieback data were analyzed using the GLIMMIX procedure in SAS ${ }^{\circledR}$ Version 9.02 (SAS Institute Inc., Cary, NC). Data for analysis were transformed to the square root scale to equalize and normalize the residuals. All significant differences are at the $P \leq 0.05$ level.

\section{Results and Discussion}

Results for the greenhouse trials show change of VMC for up to $18 \mathrm{~d}$ after initiation of the dry down period, depending on the species (Fig. 1). This is a much longer period of time when compared with a study conducted in a Michigan greenhouse trial, which found that VMC of a mixture of Sedums stopped changing after only $7 \mathrm{~d}$ with some species reaching 0\% VMC in as little as $1 \mathrm{~d}$ (VanWoert et al., 2005). The dissimilarity between studies is most likely the result of differences among species, differences in developmental stages of plants, differences in substrate depth, solar radiation intensity, container type, and possibly substrate moisture-holding capacities.

Plant relative water use, as estimated by removing the evaporative portion (i.e., nonvegetated control) of evapotranspiration, was calculated by taking the daily difference in values and then averaging over the $18 \mathrm{~d}$ period for each species (Fig. 2). Relative water use was not consistent within plant type (i.e., herbaceous, succulent). For example, the average relative water use per day for the herbaceous species ranged from $-1.53 \mathrm{VMC}$ for A. parvifolia to $-6.23 \mathrm{VMC}$ for $A$. frigida. Similarly for the succulents, the range was +2.04 VMC for $S$. 'Royal Ruby' and -5.56 VMC for $D$. nubigenum. These results for $D$. nubigenum are consistent with other research, which found that, although it is also a succulent, D. nubigenum depletes available moisture in 

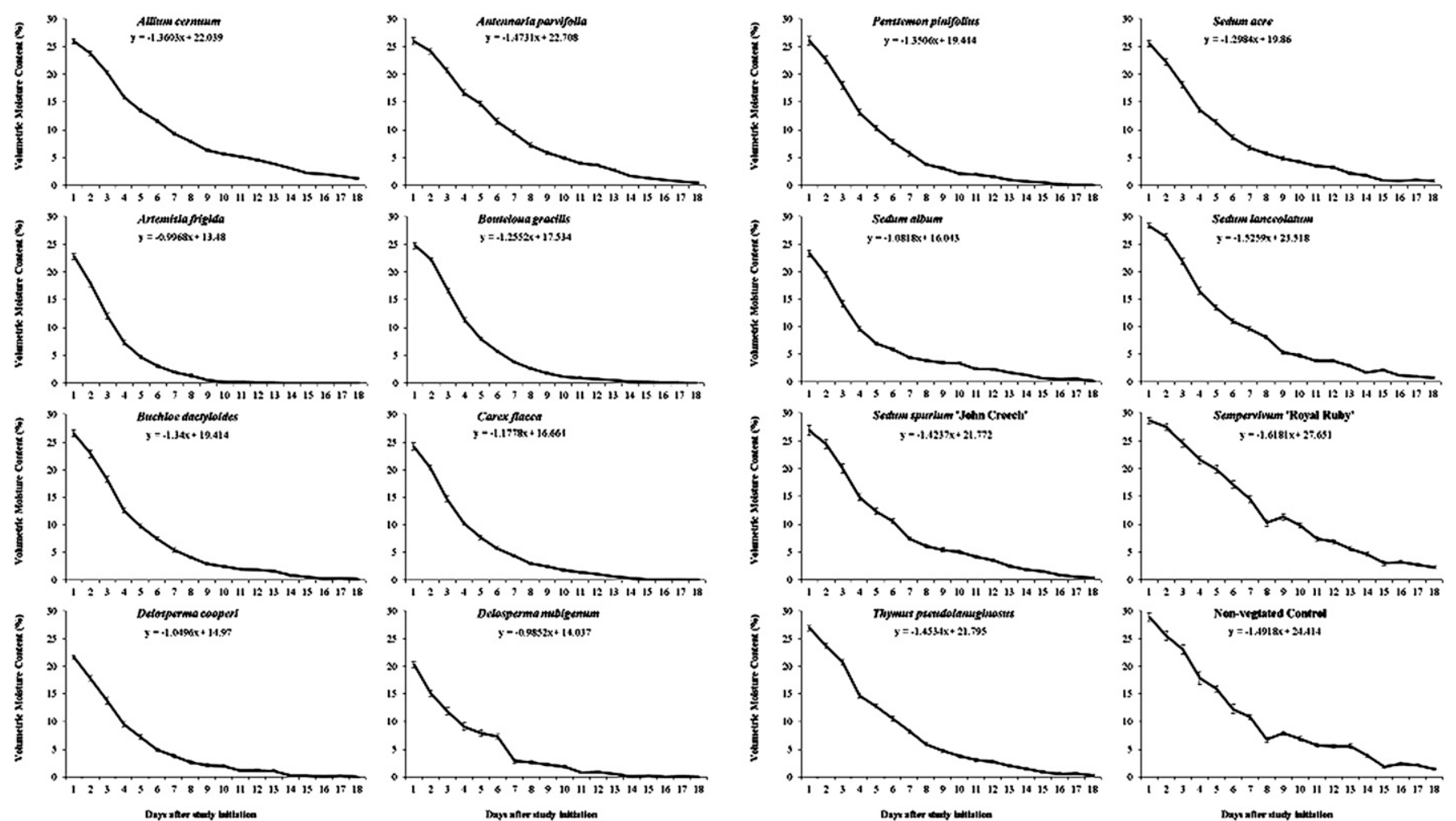

Fig. 1. Mean volumetric moisture content (VMC) of substrate for greenhouse trials by species shown as days after initiation of dry down period. Error bars represent SE.

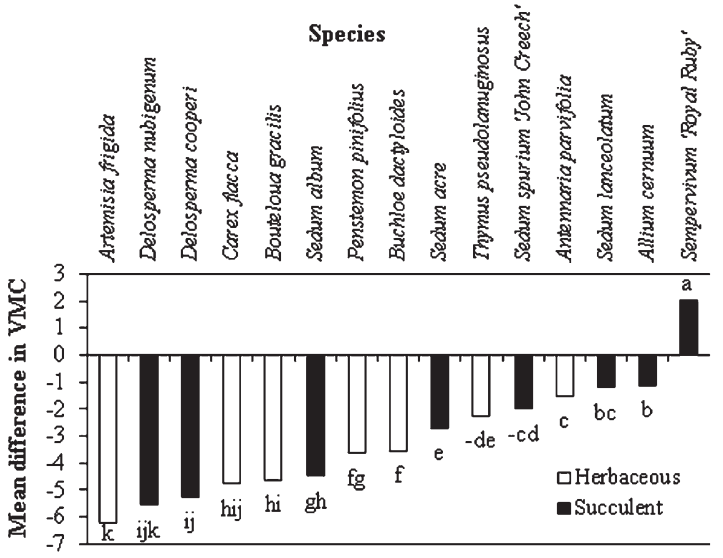

Fig. 2. Mean difference in volumetric moisture content (VMC) between the non-vegetated control and each species taken daily and averaged over the $18 \mathrm{~d}$ of the study. Lower case letters show significant differences at the $P \leq 0.05$ level.

the rhizosphere more quickly than most species of Sedum (Nagase and Thuring, 2006).

Delosperma nubigenum was not the only succulent plant to have high relative water use. Delosperma cooperi and $S$. album were very similar in relative water use to $D$. nubigenum. This agrees with research studies that evaluated response of common green roof species to substrate moisture deficit; results indicated that some species of succulent plants, especially $D$. nubigenum, use water rapidly while it is available (Berghage et al., 2007; Thuring et al., 2010).

Even $S$. acre used more water than some of the herbaceous plants such as A. parvifolia and T. pseudolanuginosus. This is in contrast to other studies that have found $S$. acre to have relatively low water use, especially when compared with the non-vegetated control (Durhman et al., 2006; Lundholm et al., 2010; Wolf and Lundholm, 2008). Differences in experimental design and environmental conditions likely contribute to the dissimilarity between results. In the current study, only one species had lower water use than the non-vegetated control, $S$. 'Royal Ruby'.

In the case of herbaceous plants such as T. pseudolanuginosus, others have also found it to be a suitable plant for green roof use as a result of its growth habit and tolerance to low moisture conditions in its rhizosphere (Sendo et al., 2007). Herbaceous plants such as $A$. parvifolia and $B$. gracilis as well as succulents $D$. cooperi and $S$. lanceolatum were all previously found to be suitable plants for use on extensive green roofs in semiarid climates (Bousselot et al., 2010). As previously documented, knowing species-specific relative water use rates will help in determining irrigation frequency (Durhman et al., 2004, 2006).

Results for number of days to top growth dieback show a clear division between the herbaceous and succulent species (Table 4). There was a nearly sixfold difference in days to dieback for the herbaceous plants versus the succulent species (Table 4). Two of the succulent species ( $S$. album and $S$. 'Royal Ruby') did not have any individuals that died back during either of the $151 \mathrm{~d}$ trials (Table 4). These are similar results to a study in Michigan where the succulent species of Sedums remained viable for the entire 4-month study period (Durhman et al., 2004). Additionally, Sedum rubrotinctum R. T. Clausen has been shown to remain alive for up to 2 years in a greenhouse without irrigation (Teeri et al., 1986).

Once the top growth of an individual plant had died back, the plant was rewatered to determine if the plant had entered into droughtinduced dormancy or died. If plants had not died during the $151 \mathrm{~d}$ study, water was applied at the end of the study to evaluate their revival rate after an extended period of drought (Table 4). The herbaceous plants had a mean of $23.51 \%$ revival, whereas the succulent species had a mean of $44.53 \%$ revival (Table 4 ). Figure 3 shows the differences in plant appearance from 
Table 4. Mean number of days to top growth dieback and percent revival after rewatering.

\begin{tabular}{lcrr}
\hline Species & Plant type & Days to dieback (SE) & Revival \\
\hline A. cernuum & $\mathrm{s}^{\mathrm{z}}$ & $59.25(1.77) \mathrm{f}$ & $91.67 \%$ \\
A. parvifolia & $\mathrm{h}$ & $22.79(0.65) \mathrm{d}$ & $31.25 \%$ \\
A. frigida & $\mathrm{h}$ & $16.08(0.32) \mathrm{a}$ & $8.33 \%$ \\
B. gracilis & $\mathrm{h}$ & $18.23(0.71) \mathrm{ab}$ & $22.92 \%$ \\
B. dactyloides & $\mathrm{h}$ & $20.19(0.90) \mathrm{bc}$ & $37.50 \%$ \\
C. flacca & $\mathrm{h}$ & $20.13(0.90) \mathrm{bc}$ & $27.08 \%$ \\
D. cooperi & $\mathrm{s}$ & $52.25(1.44) \mathrm{e}$ & $0.00 \%$ \\
D. nubigenum & $\mathrm{S}$ & $107.06(3.46) \mathrm{g}$ & $2.08 \%$ \\
P. pinifolius & $\mathrm{h}$ & $20.09(0.67) \mathrm{bc}$ & $0.00 \%$ \\
S. acre & $\mathrm{S}$ & $107.67(6.46) \mathrm{g}$ & $2.08 \%$ \\
S. album & $\mathrm{S}$ & $151.00(0.00) \mathrm{j}$ & $58.33 \%$ \\
S. lanceolatum & $\mathrm{s}$ & $138.71(2.53) \mathrm{i}$ & $54.17 \%$ \\
S. spurium 'John Creech & $\mathrm{s}$ & $127.87(3.72) \mathrm{h}$ & $56.25 \%$ \\
S. 'Royal Ruby' & $\mathrm{s}$ & $151.00(0.00) \mathrm{j}$ & $69.44 \%$ \\
T. pseudolanuginosus & $\mathrm{h}$ & $20.75(0.87) \mathrm{c}$ & $31.25 \%$ \\
Herbaceous mean & & 19.75 & $22.62 \%$ \\
Succulent mean & & 111.75 & $41.75 \%$ \\
\hline
\end{tabular}

${ }^{\mathrm{z}} \mathrm{S}=$ succulent; $\mathrm{h}=$ herbaceous.

y Lower case letters show significant differences at the $P \leq 0.05$ level.

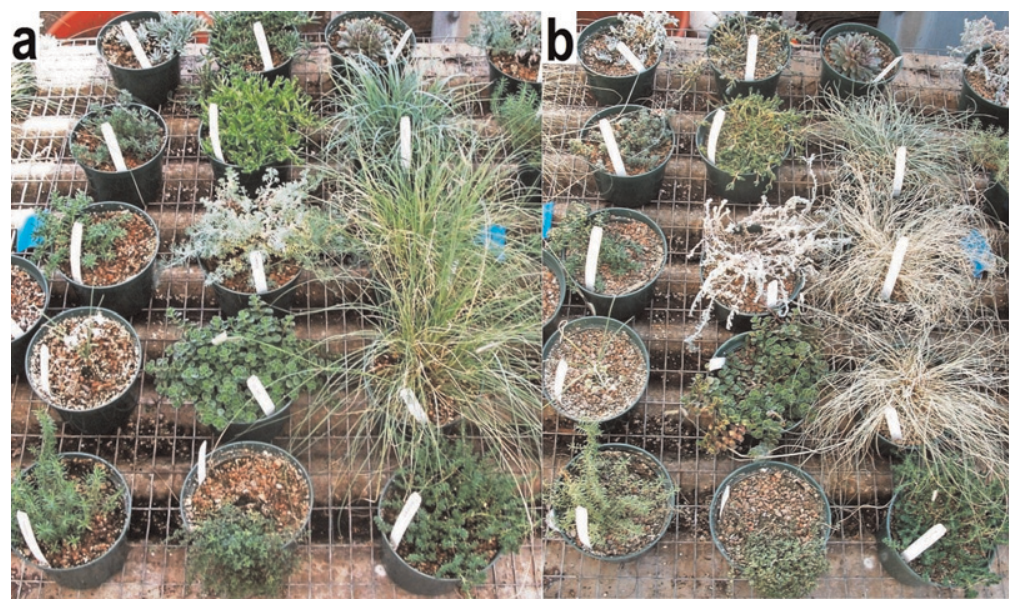

Fig. 3. Example block in the greenhouse showing the change in plant appearance (A) the day after the trial began and (B) Day 12.

the beginning of the study compared with $12 \mathrm{~d}$ later.

Based on plant relative water use and revival of species, these results suggest that succulents such as $S$. 'Royal Ruby', A. cernuum, and $S$. lanceolatum would be ideal on an extensive green roof in a semiarid environment with limited moisture content. Additionally, of the species tested here, herbaceous plants such as $A$. parvifolia, T. pseudolanuginosus, and $B$. dactyloides are the most likely to survive low moisture content of the substrate and revive once moisture is no longer limiting. Both $A$. parvifolia and $S$. lanceolatum have been successful in other extensive green roof trials in the same semiarid region (Bousselot et al., 2010).

\section{Conclusion}

There was no clear division between succulent and herbaceous species in dry down curves because there are differences within plant types. Additionally, relative water use during the $18 \mathrm{~d}$ dry down was inconsistent within plant type. However, the general trend was
Bousselot, J.M. 2010. Extensive green roofs in Colorado: Plant species performance, growing media modifications, and species response to growing media dry down. Horticulture and Landscape Architecture, Colorado State University, Fort Collins, CO.

Bousselot, J.M., J.E. Klett, and R.D. Koski. 2010. Extensive green roof species evaluations using digital image analysis. HortScience 45:12881292.

Compton, J.S. and T.H. Whitlow. 2006. A zero discharge green roof system and species selection to optimize evapotranspiration and water retention. In: Proc. of 4th North American Green Roof Conference: Greening Rooftops for Sustainable Communities, The Cardinal Group, Toronto, Boston, MA, 10-12 May 2006.

Dunnett, N. 2006. Green roofs for biodiversity: Reconciling aesthetics with ecology. In: Proc. of 4th North American Green Roof Conference: Greening Rooftops for Sustainable Communities, The Cardinal Group, Toronto, Boston, MA, 10-12 May 2006.

Dunnett, N. and N. Kingsbury. 2004. Planting options for extensive and semi-extensive green roofs, p. 221-236. In: Proc. of 2nd North American Green Roof Conference: Greening Rooftops for Sustainable Communities, The Cardinal Group, Toronto, Portland, OR, 2-4 June 2004.

Dunnett, N. and A. Nolan. 2004. The effect of substrate depth and supplementary watering on the growth of nine herbaceous perennials in a semiextensive green roof. Acta Hort. 643: 305-309.

Durhman, A.K., D.B. Rowe, and C.L. Rugh. 2006 Effect of watering regimen on chlorophyll fluorescence and growth of selected green roof plant taxa. HortScience 41:1623-1628.

Durhman, A.K., D.B. Rowe, and C.L. Rugh. 2007 Effect of substrate depth on initial growth, coverage, and survival of 25 succulent green roof plant taxa. HortScience 42:588-595.

Durhman, A.K., N.D. VanWoert, D.B. Rowe, C.L. Rugh, and D. Ebert-May. 2004. Evaluation of Crassulaceae species on extensive green roofs, p. 504-517. In: Proc. of 2nd North American Green Roof Conference: Greening Rooftops for Sustainable Communities, The Cardinal Group, Toronto, Portland, OR, 2-4 June 2004.

Emilsson, T. 2003. The influence of substrate, establishment method and species mix on plant cover, p. 305-312. In: Proc. of 1st North American Green Roof Conference: Greening Rooftops for Sustainable Communities, The Cardinal Group, Toronto, Chicago, IL, 29-30 May 2003.

Getter, K.L. and D.B. Rowe. 2006. The role of extensive green roofs in sustainable development. HortScience 41:1276-1285.

Kircher, W. 2004. Annuals and Sedum-cuttings in seed-mixtures for extensive roof gardens. Acta Hort. 643:301-303.

Latocha, P. and A. Batorska. 2007. The influence of irrigation system on growth rate and frost resistance of chosen ground cover plants on extensive green roofs, p. 131-137. Annals of Warsaw University of Life Sciences-SGGW. Horticulture and Landscape Architecture. Warsaw University of Life Sciences Press, Warsaw, Poland.

Altieri, M. and D. Letourneau. 1982. Vegetation management and biological control in agroecosystems. Crop Prot. 1:405-430.

Berghage, R., D. Beattie, A. Jarrett, and F. Rezaei. 2007. Green roof plant water use, p. 18-38. In: Berghage R., et al. (eds.). Quantifying evaporation and transpirational water losses from green roofs and green roof media capacity for neutralizing acid rain. The Pennsylvania State University, State College, PA.
Lundholm, J., J.S. MacIvor, Z. MacDougall, and M. Ranalli. 2010. Plant species and functional tem functions. PLoS ONE 5:e9677.

Miller, C. 2003. Moisture management in green roofs, p. 177-182. In: Proc. of 1st North American Green Roof Conference: Greening Rooftops for Sustainable Communities, The Cardinal Group, Toronto, Chicago, IL, 29-30 May 2003. group combinations affect green roof ecosys- 
Monterusso, M.A., D.B. Rowe, and C.L. Rugh. 2005. Establishment and persistence of Sedum spp. and native taxa for green roof applications. HortScience 40:391-396.

Nagase, A. and C. Thuring. 2006. Plant responses to drought on extensive green roofs: The effects of temperature, substrate type and substrate depth. In: Proc. of 4th North American Green Roof Conference: Greening Rooftops for Sustainable Communities, The Cardinal Group, Toronto, Boston, MA, 10-12 May 2006.

Oberndorfer, E., J. Lundholm, B. Bass, R.R. Coffman, H. Doshi, N. Dunnett, S. Gaffin, M. Köhler, K.K.Y. Liu, and B. Rowe. 2007. Green roofs as urban ecosystems: Ecological structures, functions, and services. Bioscience 57(10): 823833.

Sendo, T., N. Inagaki, M. Kanechi, and Y. Uno. 2007. What kind of plant species are the best for urban rooftop gardening? Acta Hort. 762: $333-339$.

Snodgrass, E.C. and L.L. Snodgrass. 2006. Green roof plants: A resource and planting guide. Timber Press, Portland, OR.

Teeri, J.A., M. Turner, and J. Gurevitch. 1986. The response of leaf water potential and Crassulacean acid metabolism to prolonged drought in
Sedum rubrotinctum. Plant Physiol. 81:678680.

Thuring, C.E., R.D. Berghage, and D.J. Beattie. 2010. Green roof plant responses to different substrate types and depths under various drought conditions. HortTechnology 20:395401.

VanWoert, N.D., D.B. Rowe, J.A. Andresen, C.L. Rugh, and L. Xiao. 2005. Watering regime and green roof substrate design affect Sedum plant growth. HortScience 40:659-664.

Wolf, D. and J.T. Lundholm. 2008. Water uptake in green roof microcosms: Effects of plant species and water availability. Ecol. Eng. 33:179-186. 